\title{
Chromium propionate enhances insulin sensitivity in growing cattle
}

\author{
J. W. Spears, ${ }^{\star 1}$ C. S. Whisnant, ${ }^{\star}$ G. B. Huntington, ${ }^{*}$ K. E. Lloyd, ${ }^{\star}$ R. S. Fry, ${ }^{\star}$ K. Krafka,† A. Lamptey, $\dagger$ \\ and J. Hyda† \\ *Department of Animal Science and Interdepartmental Nutrition Program, North Carolina State University, Raleigh 27695-7621 \\ †Kemin Agri Foods North America Inc., Des Moines, IA 50317
}

\begin{abstract}
Thirty-six Angus and Angus $\times$ Simmental heifers, averaging $291 \mathrm{~kg}$, were used to determine the effects of dietary $\mathrm{Cr}$, in the form of $\mathrm{Cr}$ propionate (Cr Prop), on glucose metabolism and serum insulin concentrations following glucose administration. Heifers were stratified by body weight $(\mathrm{BW})$ within a breed and randomly assigned to treatments. Treatments consisted of 0,3 , 6, or $9 \mathrm{mg}$ of supplemental $\mathrm{Cr} / \mathrm{d}$ from Cr Prop. Based on dry matter (DM) intakes, the daily doses of $\mathrm{Cr}$ were equivalent to $0.47,0.94$, and $1.42 \mathrm{mg}$ of supplemental $\mathrm{Cr} / \mathrm{kg}$ of DM. Heifers were individually fed a corn silage-based diet at a level of $2 \%$ of BW. Each heifer was also fed $0.45 \mathrm{~kg}$ of a ground corn supplement daily that served as a carrier for supplemental Cr. Glucose tolerance tests were performed on d 44 of the study. Glucose was infused via jugular catheters at a level of $0.45 \mathrm{~g} / \mathrm{kg}$ of $\mathrm{BW}^{0.75}$ over a course of 1 to $2 \mathrm{~min}$. Blood samples were collected at $-10,0,5,10,15,30,45$, $60,90,120,150$, and $180 \mathrm{~min}$ relative to glucose dosing for glucose and insulin determination. Area under the glucose response curve was lower (1,603 vs. 1,964 $\mathrm{mg} / \mathrm{dL}$ per minute) in heifers supplemented with $\mathrm{Cr}$ from 0 to $45 \mathrm{~min}$ following glucose challenge. Serum insulin concentrations were lower in Cr-supplemented heifers than in controls following glucose infusion. The molar ratio of insulin to glucose was also lower in $\mathrm{Cr}$ supplemented heifers relative to controls. Serum insulin and serum insulin to glucose ratios did not differ among heifers supplemented with 3,6 , or $9 \mathrm{mg}$ of $\mathrm{Cr} / \mathrm{d}$. Results indicate that Cr Prop supplementation increased tissue sensitivity to insulin in growing heifers. Based on insulin sensitivity, $\mathrm{Cr}$ requirements (as Cr Prop) of growing heifers can be met by supplementing with $3 \mathrm{mg}$ of $\mathrm{Cr} / \mathrm{d}$ or $0.47 \mathrm{mg}$ of $\mathrm{Cr} / \mathrm{kg}$ of DM.
\end{abstract}

Key words: chromium, insulin sensitivity, cattle

Received August 18, 2011.

Accepted November 19, 2011.

${ }^{1}$ Corresponding author: Jerry_Spears@ncsu.edu

\section{INTRODUCTION}

Chromium (Cr) functions in insulin-sensitive tissues to potentiate the action of insulin. Evidence suggests that $\mathrm{Cr}$ enhances insulin action by binding to a low molecular weight oligopeptide (chromodulin), causing amplification of insulin receptor tyrosine kinase activity (Vincent, 2001). Considerable research has been conducted with $\mathrm{Cr}$ in human nutrition, and the Institute of Medicine has established an adequate intake of $\mathrm{Cr}$ for humans (National Academies, 2001).

Several studies in cattle have indicated that $\mathrm{Cr}$ supplementation can increase glucose clearance rate (Bunting et al., 1994: Sumner et al., 2007) or reduce insulin release (Kegley et al., 1997; Stahlhut et al., 2006) following i.v. glucose administration. Chromium addition to cattle diets has also increased immune response (Spears, 2000) and increased feed intake and milk production in lactating dairy cows (Hayirli et al., 2001; McNamara and Valdez, 2005; Smith et al., 2005).

Despite considerable research that has been conducted with $\mathrm{Cr}$ in cattle, $\mathrm{Cr}$ supplementation has only recently been allowed in cattle diets in the United States. The Food and Drug Administration Center for Veterinary Medicine issued a regulatory discretion letter in July 2009, which permitted the use of $\mathrm{Cr}$ propionate $(\mathbf{C r}$ Prop) as a source of supplemental Cr in cattle diets. Chromium propionate is the only $\mathrm{Cr}$ source currently permitted for supplementation to cattle diets, and it can be added at levels up to $0.5 \mathrm{mg}$ of $\mathrm{Cr} / \mathrm{kg}$ of DM. The safety of Cr Prop has been investigated, and supplementation of lactating dairy cows with Cr Prop for $120 \mathrm{~d}$ at 4 times ( $2 \mathrm{mg}$ of $\mathrm{Cr} / \mathrm{kg}$ of DM) the permitted level did not increase $\mathrm{Cr}$ concentrations in milk, muscle, or fat (Lloyd et al., 2010). Chromium requirements of cattle, based on insulin sensitivity, are poorly defined. The present study was conducted to determine the effects of dietary Cr, as Cr Prop, on measures of insulin sensitivity in growing heifers.

\section{MATERIALS AND METHODS}

\section{Experimental Design}

Thirty-six Angus $(\mathrm{n}=24)$ and Angus $\times$ Simmental $(\mathrm{n}=12)$ heifers, approximately 12 mo of age, were used 
in the experiment. All heifers originated from cows at the NCSU Butner Beef Cattle Field Laboratory. Heifers were stratified by weaning weight within a breed and randomly assigned to 1 of 3 covered slotted-floor pens $(10 \times 5 \mathrm{~m})$, equipped with individual Calan gate feeders (American Calan, Northwood, NH). Each pen contained 8 Angus and 4 Angus $\times$ Simmental heifers. Prior to initiation of the study, heifers were trained to use the individual Calan gate feeders, and adjusted to the control diet for at least $14 \mathrm{~d}$. Care, handling, and sampling of heifers in this study were approved by the North Carolina State University Animal Care and Use Committee.

Heifers were stratified by weight within a breed, and randomly assigned to treatments within a pen. Treatments consisted of control (no supplemental Cr), 3, 6, and $9 \mathrm{mg}$ of supplemental $\mathrm{Cr} / \mathrm{d}$ from Cr Prop (KemTRACE Chromium Propionate, Kemin Agri Foods North America Inc., Des Moines, IA). Each pen included 2 blocks of Angus (heavy and lighter weight block) and 1 block of Angus $\times$ Simmental heifers. Each block was replicated 3 times (once in each of the 3 pens). Heifers averaged $294 \mathrm{~kg}$ of BW at the initiation of the study. Initiation of the study was staggered to facilitate glucose tolerance tests being conducted on the same day following initiation of dietary treatments. One pen of heifers started receiving treatments on November 26,2007 . The second and third pens of heifers started receiving treatments on November 27 and 29, 2007, respectively.

\section{Diets and Feeding}

Ingredient composition of the basal diet is shown in Table 1, and chemical composition of the basal diet is presented in Table 2. The basal diet was formulated to meet or exceed all nutrient requirements for growing heifers gaining $1.0 \mathrm{~kg} / \mathrm{d}$ (NRC, 1996). Heifers were fed once daily (morning) at a level of $2 \%$ of BW. Body weights were obtained at 14-d intervals, and feed allotments were adjusted at that time. In addition to the basal diet, each heifer was fed $0.45 \mathrm{~kg}$ (as-fed basis) of a ground corn supplement daily that provided the appropriate quantity of supplemental $\mathrm{Cr}(0,3,6$, or $9 \mathrm{mg} / \mathrm{d})$. The ground corn supplement was top-dressed on the basal diet daily. The corn supplement also provided 0.4 mg of melengestrol acetate (MGA)/head per day to suppress estrus. Experimental diets were fed for $43 \mathrm{~d}$ before conducting glucose tolerance tests.

\section{Sampling}

Orts were collected, weighed, dried at $55^{\circ} \mathrm{C}$, and then composited by animal for $\mathrm{Cr}$ determination. However,
Table 1. Ingredient composition of the basal diet

\begin{tabular}{lc}
\hline Ingredient & \% of DM \\
\hline Corn silage & 89.87 \\
Soybean meal & 8.60 \\
Urea & 0.75 \\
Calcium carbonate & 0.50 \\
Salt & 0.20 \\
Vitamin A, D, and E premix ${ }^{1}$ & 0.03 \\
Trace mineral premix & \\
Monensin & 0.03 \\
\end{tabular}

${ }^{1}$ Supplied per kilogram of diet: vitamin A 1,980 IU; vitamin D 456 IU; and vitamin E $2.0 \mathrm{IU}$.

${ }^{2}$ Supplied per kilogram of diet: zinc (as zinc sulfate) $30 \mathrm{mg}$; manganese (as manganese sulfate) $20 \mathrm{mg}$; copper (as copper sulfate) $10 \mathrm{mg}$; iodine (as calcium iodate) $0.5 \mathrm{mg}$; selenium (as sodium selenite) $0.10 \mathrm{mg}$; and cobalt (as cobalt carbonate) $0.10 \mathrm{mg}$.

because feed intake was restricted, orts were minimal. A sample of the basal diet was collected weekly during the study for DM and $\mathrm{Cr}$ analysis. Basal diet samples were composited across sampling dates for proximate analysis. Samples of the ground corn supplements were collected weekly and composited across sampling dates for DM and Cr analysis.

Body weights were recorded before feeding initially and at 14-d intervals. Jugular blood samples were collected on d 0, 21, and 42 for serum glucose, insulin, and NEFA concentrations. Blood samples were collected between 110 and 130 min postfeeding. Blood for serum glucose determination was collected in evacuated tubes containing sodium fluoride and kept on ice until centrifuged. Samples for serum insulin and NEFA were collected in evacuated tubes with no additive and kept on ice until centrifuged. All blood samples were centrifuged at $1,200 \times g$ for $20 \mathrm{~min}$ at $20^{\circ} \mathrm{C}$. Serum obtained after centrifugation was frozen at $-20^{\circ} \mathrm{C}$ until analyzed.

Table 2. Chemical composition of the basal diet

\begin{tabular}{lc}
\hline Ingredient & Amount \\
\hline $\mathrm{DM}, \%$ & 37.9 \\
$\mathrm{CP}^{1}$ & 12.8 \\
$\mathrm{ADF}^{1}$ & 25.1 \\
$\mathrm{NDF}^{1}$ & 41.9 \\
$\mathrm{TDN}^{1}$ & 68 \\
$\mathrm{Calcium}^{1}$ & 0.42 \\
Phosphorus $^{1}$ & 0.27 \\
Magnesium $^{1}$ & 0.18 \\
Potassium $^{1}$ & 0.96 \\
Sodium $^{1}$ & 0.11 \\
Sulfur $^{1}$ & 0.12 \\
Iron $^{2}$ & 153 \\
Zinc $^{2}$ & 71 \\
Copper $^{2}$ & 22 \\
Manganese $^{2}$ & 70 \\
Molybdenum $^{2}$ & 0.4 \\
Chromium $^{2}$ & 0.199 \\
\hline
\end{tabular}

${ }^{1}$ Expressed as \% of DM.

${ }^{2}$ Expressed as $\mathrm{mg} / \mathrm{kg}$ of DM. 


\section{Glucose Tolerance Test}

Glucose tolerance tests (GTT) were performed on 3 days (January 8, 9, and 11, 2008) using 1 pen of 12 heifers (3 heifers/treatment) on each day. The day before ( $d$ 43) the GTT, sterile, nonpyrogenic indwelling catheters were inserted into the left and right jugular veins. One catheter was used for glucose infusion and the other one for blood sample collection. Feed was removed at least $1 \mathrm{~h}$ before the GTT. Glucose was infused $(50 \%$ glucose solution) at a rate of $0.45 \mathrm{~g} / \mathrm{kg}$ of $\mathrm{BW}^{0.75}$ over a course of 1 to 2 min (Sumner et al., 2007). Following glucose infusion, the catheter was immediately flushed with saline. Blood samples were collected at $-10,0,5$, $10,15,30,45,60,90,120,150$, and 180 min relative to glucose dosing for serum glucose, insulin, and NEFA determinations. Following blood collection, one aliquot of blood was placed in an evacuated tube containing sodium fluoride for glucose analysis, and a second aliquot of blood was placed in an evacuated tube with no additive for insulin and NEFA determinations. Blood was kept on ice until centrifuged at $1,200 \times g$. Serum was stored at $-20^{\circ} \mathrm{C}$ until analyzed.

Glucose clearance rate and half-life following the GTT were calculated as described by Kaneko (1989). Areas under the glucose and insulin response curves relative to basal concentrations were calculated using trapezoidal geometry. Insulin:glucose ratios were calculated on a molar basis (pmol of insulin:mmol of glucose).

\section{Laboratory Analysis}

Dry matter contents of basal diet, supplement, and ort samples were measured at $55^{\circ} \mathrm{C}$ in a forced air oven. Analysis of the basal diet for chemical components was conducted at a commercial laboratory (Dairy One Forage Laboratory, Ithaca, NY). Samples of basal diet, supplements, and orts were prepared for $\mathrm{Cr}$ analysis by wet ashing with trace metal grade nitric acid (Trace Metal grade, Fisher Scientific, Raleigh, NC) using a hot plate digestion procedure. Chromium was measured by electrothermal atomic absorption spectrophotometry (model 6701/6601, Shimadzu, Kyoto, Japan) as described previously (Lloyd et al., 2010). The method of standard addition was used to remove matrix effects. Each sample plus standard was run in duplicate. Bovine muscle obtained from the National Institute of Standards and Technology (Washington, DC) and certified to contain $71 \pm 38 \mathrm{ng}$ of $\mathrm{Cr} / \mathrm{g}$ was used as a reference standard.

Serum glucose was measured using the glucose hexokinase assay kit (GAHK-20, Sigma-Aldrich Inc., St. Louis, MO). Serum insulin concentrations were determined using a radioimmunoassay kit (Siemens Healthcare Diagnostics, Los Angeles, CA) with a bovine insulin standard curve and internal assay standards prepared from bovine insulin (I-5500, Sigma-Aldrich) used in the place of the standards supplied with the kit. The insulin assay was validated for bovine serum using guidelines of the National Committee for Clinical Laboratory Standards (NCCLS, 2004). Serum NEFA concentrations were determined enzymatically using the NEFA-C kit (Wako Diagnostics, Richmond, $\mathrm{VA})$.

\section{Statistical Analysis}

Serum glucose, insulin, and NEFA concentrations from the GTT were analyzed statistically using repeated measures and the MIXED procedure of SAS (version 9.2, 2010; SAS Institute, Cary, NC) for a randomized complete block design. The model included treatment, block, time, treatment $\times$ block, treatment $\times$ time, and block $\times$ time. Treatment $\times$ block and block $\times$ time interactions were not significant for any of the variables, and were removed from the analysis. The average of the -10 and 0 time samples was used as the basal or 0 time sample for glucose and insulin in the repeated-measures analysis. When the treatment $\times$ time interaction was significant, data were analyzed by time. Glucose clearance rate, half-life, area under the curve, and basal and peak concentrations of glucose and insulin were analyzed using the MIXED procedure. Serum data from the individual bleedings on $\mathrm{d} 0,21$, and 42 were analyzed by day using the MIXED procedure. Day 0 values were used as a covariate when analyzing data for d 21 and 42. Differences among treatments were determined using single degree of freedom contrasts. Comparisons made were (1) control versus Cr treatments $(3,6$, and $9 \mathrm{mg}$ of $\mathrm{Cr} / \mathrm{d}$ ), (2) 3 versus $6 \mathrm{mg}$ of $\mathrm{Cr} / \mathrm{d}$, and (3) 6 versus $9 \mathrm{mg}$ of $\mathrm{Cr} / \mathrm{d}$.

\section{RESULTS AND DISCUSSION}

The basal diet averaged $0.199 \mathrm{mg}$ of $\mathrm{Cr} / \mathrm{kg}$ of $\mathrm{DM}$ (Table 2), with weekly samples obtained during the study ranging from 0.126 to $0.268 \mathrm{mg}$ of $\mathrm{Cr} / \mathrm{kg}$ of $\mathrm{DM}$. Initial and final $\mathrm{BW}$ were similar across treatments (Table 3). Dry matter intake was also similar for all treatment groups. Based on average DM intake, supplemental $\mathrm{Cr}$ concentrations in the Cr-supplemented diets averaged $0.47,0.94$, and $1.42 \mathrm{mg}$ of $\mathrm{Cr} / \mathrm{kg}$ of $\mathrm{DM}$, for heifers receiving 3,6 , and $9 \mathrm{mg}$ of $\mathrm{Cr} / \mathrm{d}$, respectively (Table 3). Chromium supplementation did not affect serum glucose, insulin, or NEFA concentrations in samples collected at approximately $2 \mathrm{~h}$ postfeeding on d 21 and 42 (data not shown). 
Table 3. Effects of dietary $\mathrm{Cr}$ on heifer BW and feed intake

\begin{tabular}{lccccc}
\hline & \multicolumn{4}{c}{ Supplemental chromium, mg/d } \\
\cline { 2 - 5 } Item & 0 & 3 & 6 & 9 & SE \\
\hline BW, $\mathrm{kg}$ & & & & \\
Initial & 289.7 & 293.1 & 291.9 & 288.6 & 4.0 \\
Day 42 & 339.4 & 341.3 & 339.2 & 341.7 & 4.3 \\
DM intake, $\mathrm{kg} / \mathrm{d}$ & 6.36 & 6.40 & 6.36 & 6.36 & 0.08 \\
Supplemental Cr, $\mathrm{mg} / \mathrm{kg}$ of $\mathrm{DM}^{1}$ & - & 0.47 & 0.94 & 1.42 & \\
\hline${ }^{1}$ Based on daily supplemental $\mathrm{Cr}$ intake & &
\end{tabular}

Data from one heifer in the control treatment was not included in the GTT results due to complications of venal cannulation. Serum insulin concentrations following the GTT were affected by treatment $(P=$ $0.01)$ and time $(P=0.01)$, and tended to be affected by a treatment $\times$ time interaction $(P=0.07)$ when analyzed by repeated measures (Table 4 ). Basal insulin concentrations before glucose infusion were similar across treatments. However, following glucose infusion, the amount of insulin released was considerably lower in heifers fed supplemental Cr compared with controls (Figure 1). Serum insulin concentrations were higher in controls relative to Cr-supplemented heifers at $10(P=$ $0.05)$ and $15 \min (P=0.01)$, and tended $(P=0.11)$ to be higher at 5 and 30 min after glucose administration. By 45 min after glucose administration, insulin levels were similar in control and Cr-supplemented heifers. Insulin concentrations did not differ among heifers supplemented with 3,6 , or $9 \mathrm{mg}$ of $\mathrm{Cr} / \mathrm{d}$.

Peak serum insulin values after glucose infusion were higher $(P=0.02)$ in controls (Table 5$)$. The change in insulin from basal concentrations (peak - basal) was also lower $(P=0.02)$ for $\mathrm{Cr}$-supplemented treatments compared with control. Area under the insulin response curve was lower $(P=0.03)$ in heifers supplemented with $\mathrm{Cr}$ compared with controls from 0 to $15(P=$ $0.04), 0$ to $30(P=0.02)$, and 0 to $45 \mathrm{~min}(P=0.03)$ following glucose infusion (Table 5). In agreement with the present study, Cr supplementation from several different forms reduced insulin concentrations following glucose infusion in milk-fed calves (Kegley et al., 1997), prepartum (Subiyatno et al., 1996) and postpartum dairy cows (Hayirli et al., 2001), and postpartum beef cows (Stahlhut et al., 2006). Chromium supplementation also reduced insulin secretion following glucose dosing in rats (Striffler et al., 1995) and hyperglycemic humans (Anderson et al., 1991) fed low Cr diets. In the present study, peak insulin concentrations and area under the response curve did not differ among heifers supplemented with 3,6 , or $9 \mathrm{mg}$ of $\mathrm{Cr} / \mathrm{d}$.

Repeated-measures analysis indicated that serum glucose concentrations were affected by block $(P=$ $0.01)$ and time $(P=0.01)$, and tended $(P=0.12)$ to be affected by a treatment $\times$ time interaction (Table 4 ). The significant effect of block would relate to small day differences in serum glucose concentrations. However, serum glucose was not affected by a treatment $\times$ block or block $\times$ time interaction. Analyzed across sampling times, serum glucose concentrations were higher $(P=$ 0.05) in Cr-supplemented heifers compared with con-

Table 4. Least squares means across sampling times and ANOVA of serum glucose, insulin, insulin:glucose ratio, and NEFA using repeated measures

\begin{tabular}{|c|c|c|c|c|}
\hline Item & $\begin{array}{l}\text { Glucose, } \\
\mathrm{mg} / \mathrm{dL}\end{array}$ & $\begin{array}{l}\text { Insulin, } \\
\mu \mathrm{IU} / \mathrm{mL}\end{array}$ & $\begin{array}{l}\text { Insulin:glucose, } \\
\text { pmol/L:mmol/L }\end{array}$ & $\begin{array}{l}\text { NEFA, } \\
\mu \mathrm{Eq} / \mathrm{L}\end{array}$ \\
\hline \multicolumn{5}{|l|}{ Treatment } \\
\hline Control & 109.0 & 78.0 & 68.6 & 99.7 \\
\hline $3 \mathrm{mg}$ of $\mathrm{Cr} / \mathrm{d}$ & 114.2 & 63.3 & 56.2 & 105.0 \\
\hline $6 \mathrm{mg}$ of $\mathrm{Cr} / \mathrm{d}$ & 112.5 & 57.8 & 52.1 & 141.5 \\
\hline $9 \mathrm{mg}$ of $\mathrm{Cr} / \mathrm{d}$ & 114.1 & 64.3 & 57.7 & 118.0 \\
\hline $\mathrm{SE}$ & 1.9 & 3.8 & 3.6 & 12.0 \\
\hline Treatment & 0.23 & 0.01 & 0.03 & 0.09 \\
\hline 0 vs. Cr & 0.05 & 0.01 & 0.01 & 0.15 \\
\hline 3 vs. $6 \mathrm{mg}$ of $\mathrm{Cr} / \mathrm{d}$ & 0.52 & 0.31 & 0.42 & 0.04 \\
\hline 6 vs. $9 \mathrm{mg}$ of $\mathrm{Cr} / \mathrm{d}$ & 0.54 & 0.23 & 0.27 & 0.17 \\
\hline Block & 0.01 & 0.68 & 0.71 & 0.96 \\
\hline Time & 0.01 & 0.01 & 0.01 & 0.01 \\
\hline Treatment $\times$ time & 0.12 & 0.09 & 0.71 & 0.60 \\
\hline Treatment $\times$ block & 0.28 & 0.83 & 0.54 & 0.21 \\
\hline Block $\times$ time & 0.31 & 0.88 & 0.42 & 0.37 \\
\hline
\end{tabular}




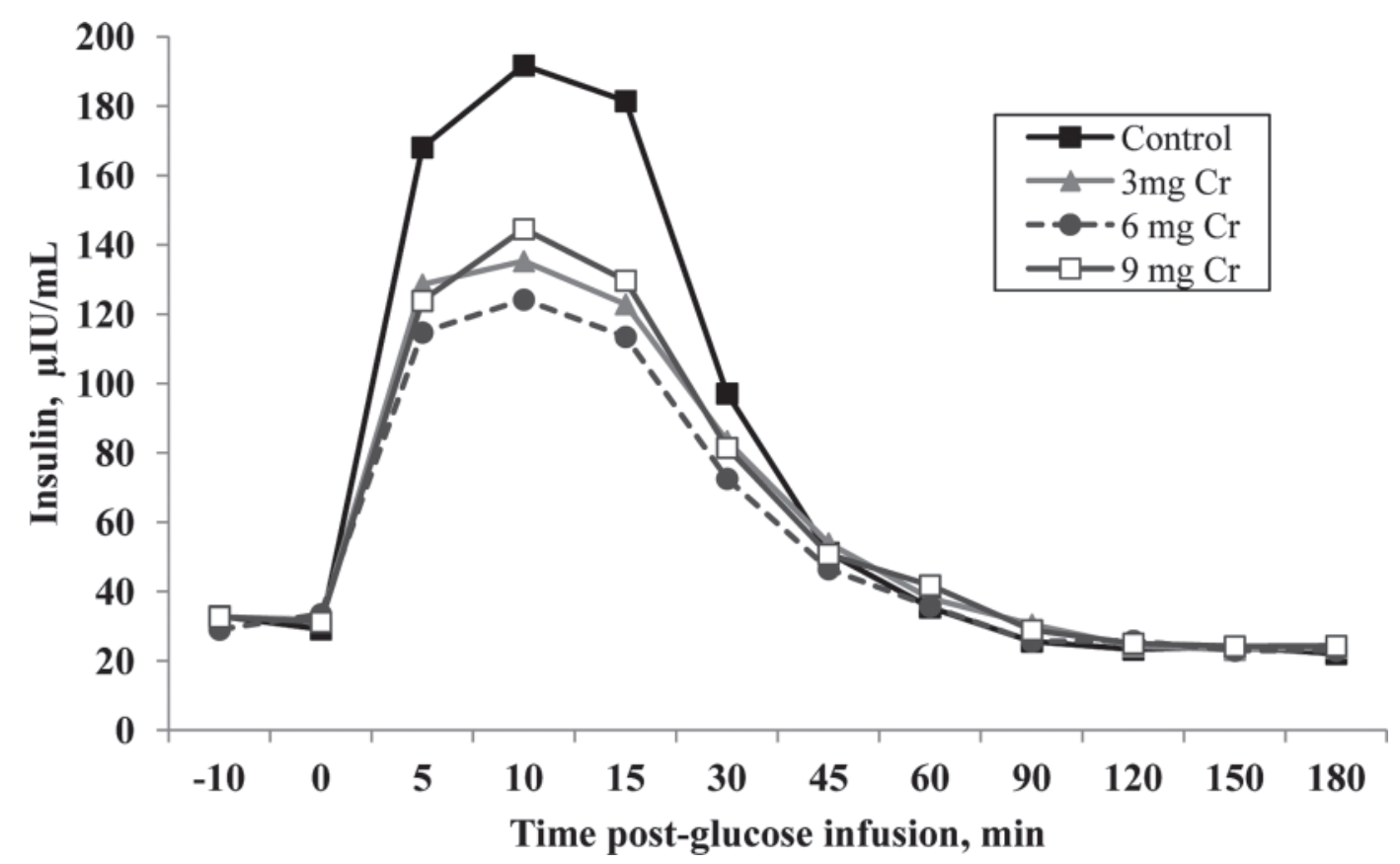

Figure 1. Effect of dietary $\mathrm{Cr}$, from Cr propionate (Cr Prop), on serum insulin concentrations in heifers following a glucose tolerance test. Pooled SE $=3.8$. Control versus $C r$ treatments $(P=0.01)$, time $(P=0.01)$, and treatment $\times$ time $(P=0.09)$.

trols. When analyzed by sampling time, control heifers had lower serum glucose concentrations at $60(P=$ 0.02), $90(P=0.01)$, and $120 \mathrm{~min}(P=0.01)$ following glucose challenge than those supplemented with $\mathrm{Cr}$ Prop (Figure 2). Serum glucose concentration did not differ among heifers supplemented with 3,6 , or $9 \mathrm{mg}$ of $\mathrm{Cr} / \mathrm{d}$.

Glucose kinetics data following the GTT are presented in Table 5. Basal serum glucose concentrations tended $(P=0.15)$ to be lower in controls compared

Table 5. Effects of dietary $\mathrm{Cr}$ on glucose and insulin kinetics following a glucose tolerance test

\begin{tabular}{|c|c|c|c|c|c|c|c|c|}
\hline Item & \multicolumn{4}{|c|}{ Supplemental chromium, mg/d } & SE & \multicolumn{3}{|c|}{ Contrast ( $P$-value $)$} \\
\hline Basal concentration, $\mathrm{mg} / \mathrm{dL}$ & 84.2 & 90.4 & 87.0 & 96.9 & 4.0 & 0.15 & 0.54 & 0.09 \\
\hline Peak concentration, mg/dL & 155.7 & 152.3 & 148.1 & 152.4 & 5.1 & 0.48 & 0.55 & 0.55 \\
\hline Change, ${ }^{1} \mathrm{mg} / \mathrm{dL}$ & 71.5 & 61.9 & 61.1 & 55.5 & 2.9 & 0.01 & 0.85 & 0.18 \\
\hline 15 to $45 \mathrm{~min}$ & 0.99 & 0.61 & 0.69 & 0.71 & 0.07 & 0.01 & 0.39 & 0.90 \\
\hline \multicolumn{9}{|l|}{ Half-life, min } \\
\hline 5 to $15 \mathrm{~min}$ & 689.6 & 64.9 & 106.6 & 71.2 & 326.0 & 0.14 & 0.93 & 0.94 \\
\hline 15 to $45 \mathrm{~min}$ & 72.9 & 117.5 & 111.4 & 104.5 & 9.6 & 0.01 & 0.65 & 0.61 \\
\hline \multicolumn{9}{|c|}{ Area under the curve, $\mathrm{mg} / \mathrm{dL}$ per min } \\
\hline 0 to $15 \min$ & 781 & 691 & 657 & 588 & 38 & 0.01 & 0.53 & 0.21 \\
\hline 0 to $30 \mathrm{~min}$ & 1,498 & 1,324 & 1,247 & 1,063 & 75 & 0.01 & 0.46 & 0.09 \\
\hline \multicolumn{9}{|c|}{ Area under the curve, $\mu \mathrm{IU} / \mathrm{mL}$ per min } \\
\hline 0 to $15 \min$ & 1,844 & 1,222 & 1,092 & 1,266 & 250 & 0.04 & 0.71 & 0.62 \\
\hline 0 to $30 \mathrm{~min}$ & 3,524 & 2,284 & 2,019 & 2,373 & 443 & 0.02 & 0.67 & 0.57 \\
\hline 0 to $45 \mathrm{~min}$ & 4,204 & 2,830 & 2,443 & 2,888 & 546 & 0.03 & 0.61 & 0.56 \\
\hline
\end{tabular}

${ }^{1}$ Peak - basal concentration. 


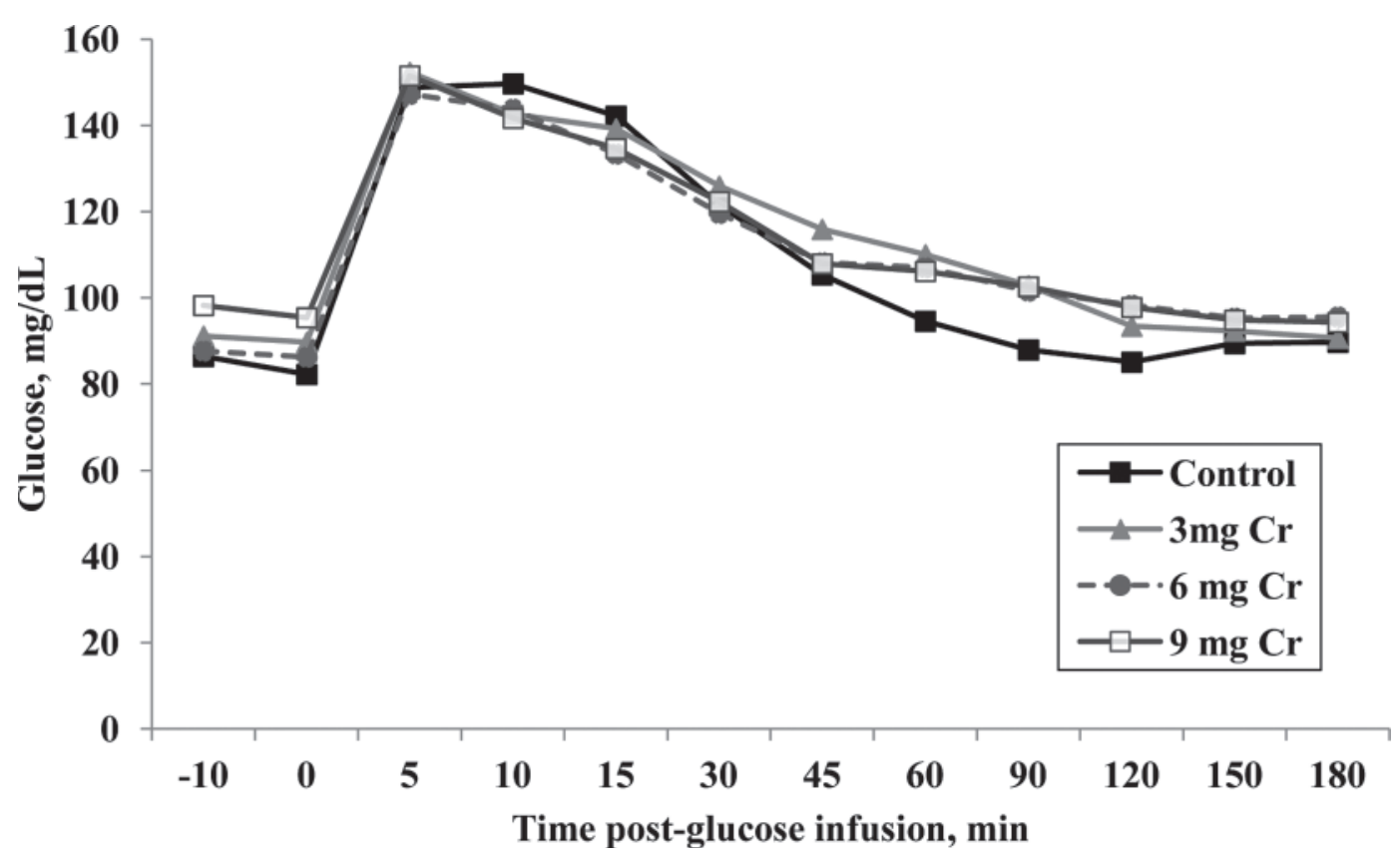

Figure 2. Effect of dietary Cr, from Cr propionate (Cr Prop), on serum glucose concentrations in heifers following a glucose tolerance test. Pooled SE $=1.9$. Control versus Cr treatments $(P=0.05)$, time $(P=0.01)$, and treatment $\times$ time $(P=0.12)$.

with Cr-supplemented heifers. Sumner et al. (2007) observed a trend for control heifers to have lower basal glucose levels than those supplemented with 10 or 15 $\mathrm{mg}$ of $\mathrm{Cr} / \mathrm{d}$, as Cr Prop. Heifers supplemented with 6 $\mathrm{mg}$ of $\mathrm{Cr} / \mathrm{d}$ tended $(P=0.09)$ to have lower basal glucose concentrations than those receiving $9 \mathrm{mg}$ of $\mathrm{Cr} / \mathrm{d}$.

Peak serum glucose concentrations did not differ among treatments (Table 5). However, the change (peak - basal) in serum glucose from basal concentrations was less $(P<0.01)$ in heifers supplemented with 3,6 , or $9 \mathrm{mg}$ of $\mathrm{Cr} / \mathrm{d}$ compared with controls. Variation in glucose clearance rate from 5 to $15 \mathrm{~min}$ following infusion was substantial but a trend $(P=0.08)$ was still observed for higher glucose clearance rate in Cr-supplemented heifers during this period. This suggests that control heifers were less able to clear glucose shortly after glucose infusion. From 15 to 45 min following glucose administration, glucose clearance rate was higher $(P=0.01)$, whereas the glucose half-life was lower in controls relative to heifers supplemented with 3,6 , or $9 \mathrm{mg}$ of $\mathrm{Cr} / \mathrm{d}$. The higher glucose clearance rate in controls (between 15 and $45 \mathrm{~min}$ ) occurred after the large increase in serum insulin levels observed in this group at 10 and 15 min following infusion of glucose.

Area under the glucose response curve was lower for heifers supplemented with $\mathrm{Cr}$ compared with controls regardless of whether area under the curve was calculated from 0 to $15 \mathrm{~min}(P=0.01), 0$ to $30 \mathrm{~min}(P$ $=0.01)$, or 0 to $45 \mathrm{~min}(P=0.03)$. Area under the curve reflects both the increase in glucose concentration above basal level and the rate of glucose clearance. Heifers supplemented with $9 \mathrm{mg}$ of $\mathrm{Cr} / \mathrm{d}$ tended to have a lower area under the glucose curve from 0 to $30(P$ $=0.09)$ and 0 to $45 \mathrm{~min}(P=0.10)$ following glucose infusion. Area under the curve did not differ among heifers supplemented with 3 and $6 \mathrm{mg}$ of $\mathrm{Cr} / \mathrm{d}$.

Inconsistent results have been obtained in previous studies evaluating the effect of $\mathrm{Cr}$ supplementation on glucose metabolism in cattle. Chromium supplementation from Cr picolinate (Bunting et al., 1994) or Cr Prop (Sumner et al., 2007) increased clearance rate and reduced area under the glucose response curve following glucose infusion in growing cattle. In other studies (Subiyatno et al., 1996; Kegley et al., 1997; Hayirli et al., 2001; Stahlhut et al., 2006), Cr supplementation reduced serum insulin concentrations following glucose infusion without increasing glucose clearance rate. Several factors, such as level or bioavailability of $\mathrm{Cr}$ in the control diet, type of diet (i.e., energy level), physiological state of the animal, length of time $\mathrm{Cr}$ was supplemented before measurements, and technical aspects of conducting a GTT, may contribute to the variable responses in glucose metabolism to $\mathrm{Cr}$ supplementation in cattle.

The higher serum glucose concentrations in Cr-supplemented compared with control heifers at 60 and 90 min following glucose administration suggests that $\mathrm{Cr}$ increased endogenous glucose entry into the blood. Se- 


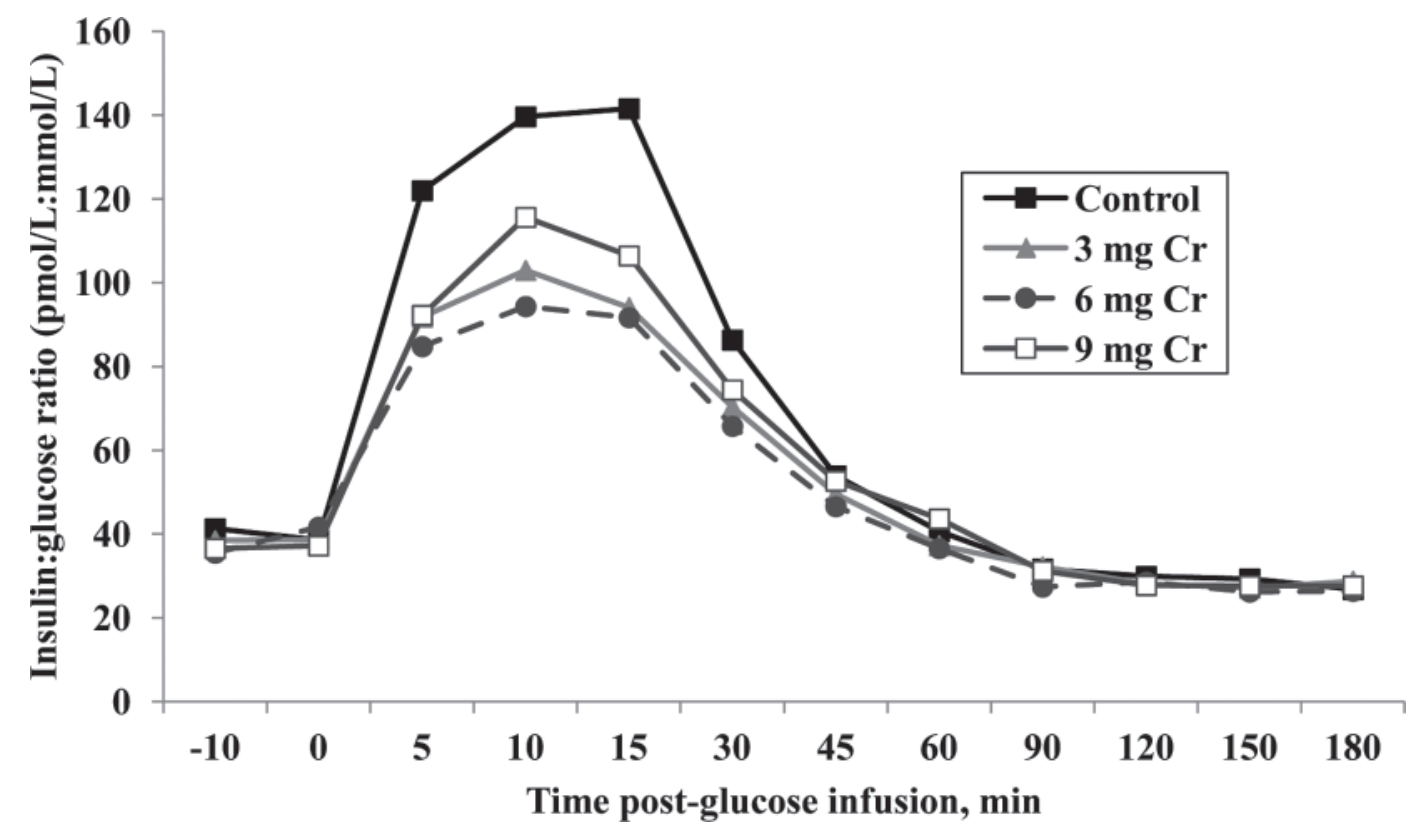

Figure 3. Effect of dietary Cr, from Cr propionate (Cr Prop), on serum insulin:glucose ratios in heifers following a glucose tolerance test. Pooled $\mathrm{SE}=3.6$. Control versus $\mathrm{Cr}$ treatments $(P=0.01)$ and time $(P=0.01)$.

rum glucose of heifers in the present study would have been derived from both exogenous (infused) and endogenous sources (gluconeogenesis and glycogenolysis) of glucose. Ruminants are dependent on gluconeogenesis for a major portion of their glucose requirement. Gluconeogenesis increases after feeding in ruminants because of increased availability of gluconeogenic precursors (Weekes, 1991). Heifers were fed before glucose infusion with feed removed at least $1 \mathrm{~h}$ before the procedure. Therefore, gluconeogenesis was probably occurring to a high degree when heifers were challenged with glucose. It has been shown that intravenous glucose infusion only partially depresses endogenous glucose production in ruminants (Weekes, 1991). Serum glucagon was not measured in the present study. However, higher glucagon concentrations in Cr-supplemented heifers could explain the higher serum glucose concentration at 60 and 90 min after glucose dosing. Previous studies (Sartin et al., 1985; Hayirli et al., 2001) in dairy cows have indicated that glucagon decreases following intravenous glucose infusion but then starts to increase by 60 to 90 min following glucose dosing. Insulin appears to act in concert with elevated blood glucose to inhibit glucagon secretion from the pancreas (Greenbaum et al., 1991). Glucagon secretion may have been inhibited to a lesser degree in Cr-supplemented heifers because of their lower serum insulin levels immediately following glucose dosing. Glucagon increases glucose release into the blood by stimulating gluconeogenesis and glycogenolysis (Brockman, 1986). Intravenous infusion of glucagon increased plasma glucose and reduced liver glycogen in lactating dairy cows (Hippen et al., 1999). Dairy cows supplemented with $\mathrm{Cr}$ had a greater increase in serum glucose following intravenous propionate infusion, suggesting that $\mathrm{Cr}$ increased gluconeogenesis from propionate (Subiyatno et al., 1996). Chromium-supplemented cows also had a lower serum insulin:glucagon ratio following propionate infusion than control cows (Subiyatno et al., 1996).

The molar ratio of insulin to glucose was affected by treatment $(P=0.02)$ and time $(P=0.01$; Table 4 ; Figure 3$)$. Insulin:glucose ratio was higher $(P=0.01)$ in control heifers relative to those supplemented with Cr. In heifers supplemented with $\mathrm{Cr}$, insulin:glucose ratio did not differ among treatment groups.

Results obtained in the present study are consistent with numerous cattle studies (Kegley et al., 1997; Stahlhut et al., 2006) indicating that Cr facilitates insulin action. The much lower serum insulin concentration observed shortly after glucose infusion in heifers supplemented with Cr Prop suggests that their tissues were more sensitive to insulin. The smaller increase in serum glucose after glucose infusion also indicates that insulin in heifers supplemented with $\mathrm{Cr}$ was able to respond more rapidly in regard to increasing glucose uptake following glucose loading. In response to increased blood glucose, insulin enhances glucose uptake in muscle and adipose tissue by causing redistribution of a specific glucose transporter (GLUT-4) from intracellular storage sites to the plasma membrane (McGrane, 2000). In- 


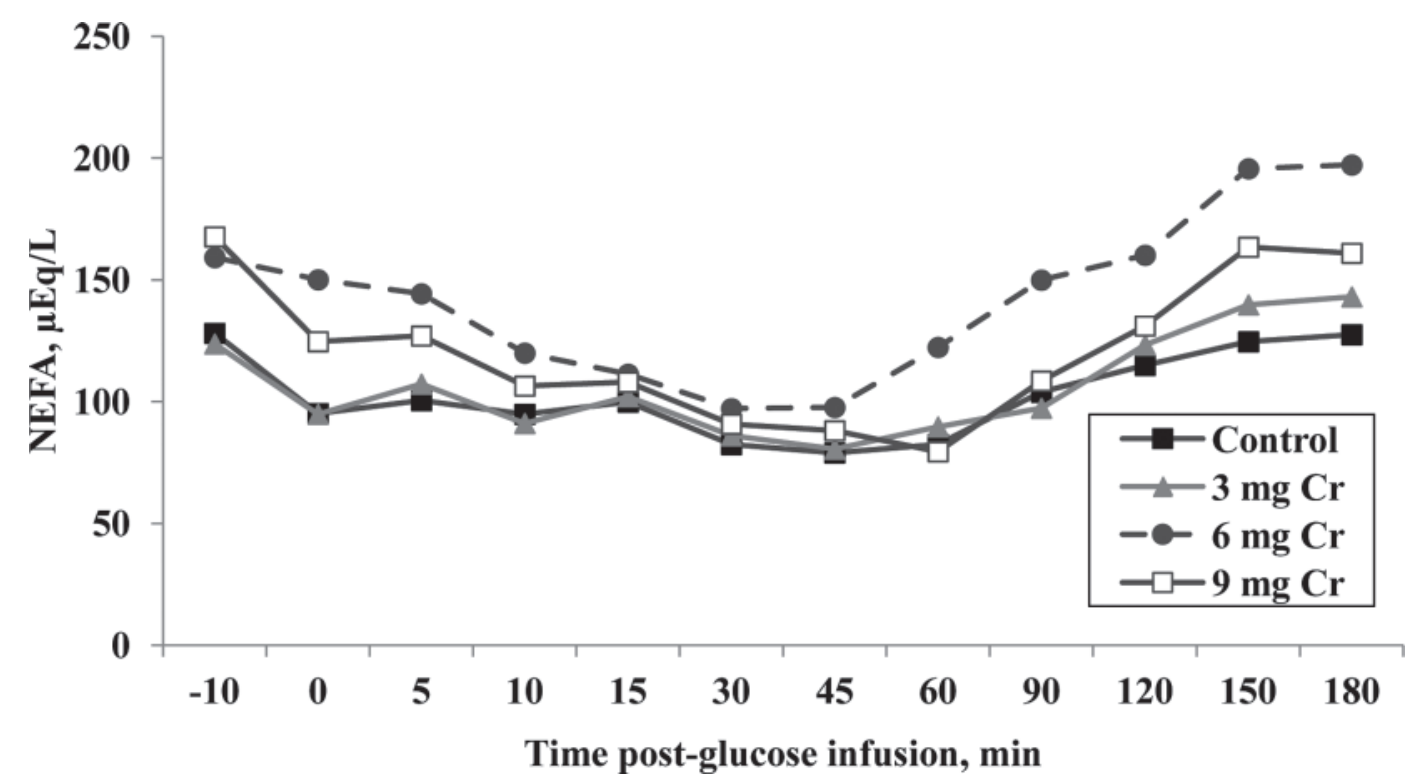

Figure 4. Effect of dietary $\mathrm{Cr}$, from Cr propionate (Cr Prop), on serum NEFA concentrations in heifers following a glucose tolerance test. Pooled $\mathrm{SE}=12.0$. Three milligrams of $\mathrm{Cr}$ versus $6 \mathrm{mg}$ of $\mathrm{Cr}(P=0.04)$ and time $(P=0.01)$.

sulin also promotes liver storage of glucose as glycogen via activation of enzymes involved in glycogen synthesis (McGrane, 2000). Chromium has been proposed to potentiate insulin action by binding to apochromodulin in insulin-sensitive cells (Vincent, 2001). In response to increased blood glucose and insulin concentrations, $\mathrm{Cr}$ in blood is believed to move into insulin-sensitive cells loading apochromodulin to form chromodulin, which then activates tyrosine kinase activity in insulin receptors (Vincent, 2001).

Heifers were fed MGA in the present study to avoid having heifers at different stages of the estrous cycle during the GTT. Feeding MGA might have affected responses to the GTT. Melengestrol acetate is a synthetic progestin that acts like progesterone, which has been shown to decrease insulin sensitivity in rats $(\mathrm{Ku}-$ magai et al., 1993). An implant containing estradiol and progesterone increased insulin resistance in steers administered Escherichia coli lipopolysaccharide to induce endotoxemia (McMahon et al., 1998). In vitro addition of MGA to muscle cells isolated from heifers and steers also increased expression of IGF-I (Sissom et al., 2006). Insulin-like growth factor-I can bind to insulin receptors and could affect glucose tolerance. In the present study, all heifers received MGA so any effect of MGA on insulin sensitivity should be balanced across treatments.

Serum NEFA concentrations decreased shortly after glucose infusion and then began increasing at approximately 60 min postinfusion (Table 4; Figure 4; time effect, $P=0.01)$. Heifers supplemented with $6 \mathrm{mg}$ of
$\mathrm{Cr} / \mathrm{d}$ had higher $(P<0.05)$ NEFA concentrations than those receiving $3 \mathrm{mg}$ of $\mathrm{Cr} / \mathrm{d}$. It is unclear why serum NEFA concentrations were higher in heifers receiving 6 mg of Cr/d. Previous studies (Hayirli et al., 2001; Sumner et al., 2007) have indicated variable effects of $\mathrm{Cr}$ on NEFA concentrations following glucose administration.

\section{CONCLUSIONS}

This study indicates that supplementing growing heifers with Cr Prop reduces the secretion of insulin following a glucose challenge. Area under the glucose curve was lower from 0 to $45 \mathrm{~min}$ following glucose infusion in heifers supplemented with $\mathrm{Cr}$, indicating that the reduced insulin secretion did not compromise glucose uptake following glucose administration. This indicates that $\mathrm{Cr}$ Prop increased tissue sensitivity to insulin. All 3 dosages of $\mathrm{Cr}(3,6$, and $9 \mathrm{mg} / \mathrm{d})$ evaluated in this study increased insulin sensitivity, and responses were generally similar for the different levels of supplemental Cr. This suggest that, based on insulin sensitivity, $\mathrm{Cr}$ requirements of growing heifers can be met by supplementing with $3 \mathrm{mg}$ of $\mathrm{Cr} / \mathrm{d}$ (equivalent to $0.47 \mathrm{mg}$ of $\mathrm{Cr} / \mathrm{kg}$ of diet DM) from Cr Prop.

\section{ACKNOWLEDGMENTS}

The authors acknowledge Greg Shaeffer, Dean Askew, and the staff of the Butner Beef Educational Unit at North Carolina State University for their assistance in conducting this study. Appreciation is also expressed 
to Matt Newhouse (Kemin Agri Foods North America Inc., Des Moines, IA) for his support in planning, conducting, and monitoring this study and accompanying data with the use of good laboratory practices.

\section{REFERENCES}

Anderson, R. A., M. M. Polansky, N. A. Bryden, and J. J. Canary. 1991. Supplemental-chromium effects on glucose, insulin, glucagon, and urinary chromium losses in subjects consuming controlled low-chromium diets. Am. J. Clin. Nutr. 54:909-916.

Brockman, R. P. 1986. Pancreatic and adrenal hormonal regulation of metabolism. Pages 405-419 in Control of Digestion and Metabolism in Ruminants. L. P. Milligan, W. L. Grovum, and A. Dodson, ed. Prentice-Hall, Englewood Cliffs, NJ.

Bunting, L. D., J. M. Fernandez, D. L. Thompson, and L. L. Southern. 1994. Influence of chromium picolinate on glucose usage and metabolic criteria in growing Holstein calves. J. Anim. Sci. $72: 1591-1599$.

Greenbaum, C. J., P. J. Havel, G. J. Taborsky Jr., and L. J. Klaff. 1991. Intra-islet insulin permits glucose to directly suppress pancreatic A cell function. J. Clin. Invest. 88:767-773.

Hayirli, A., D. R. Bremmer, S. J. Bertics, M. T. Socha, and R. R. Grummer. 2001. Effect of chromium supplementation on production and metabolic parameters in periparturient dairy cows. J. Dairy Sci. 84:1218-1230.

Hippen, A. R., P. She, J. W. Young, D. C. Beitz, G. L. Linberg, L. F. Richardson, and R. W. Tucker. 1999. Metabolic responses of dairy cows and heifers to various intravenous dosages of glucagon. J. Dairy Sci. 82:1128-1138.

Kaneko, J. J. 1989. Carbohydrate metabolism and its diseases. Pages 44-85 in Clinical Biochemistry of Domestic Animals. 4th ed. J. J. Kaneko, ed. Academic Press, San Diego, CA.

Kegley, E. B., J. W. Spears, and J. H. Eisemann. 1997. Performance and glucose metabolism in calves fed a chromium-nicotinic acid complex or chromium chloride. J. Dairy Sci. 80:1744-1750.

Kumagai, S., A. Holmarg, and P. Bjornthorp. 1993. The effect of estrogen and progesterone on insulin sensitivity in rats. Acta Physiol. Scand. 149:91-97.

Lloyd, K. E., V. Fellner, S. J. McLeod, R. S. Fry, K. Krafka, A. Lamptey, and J. W. Spears. 2010. Effects of supplementing dairy cows with chromium propionate on milk and tissue chromium concentrations. J. Dairy Sci. 93:4774-4780.

McGrane, M. M. 2000. Carbohydrate metabolism-Synthesis and oxidation. Pages 158-210 in Biochemical and Physiological Aspects of Human Nutrition. M. H. Stipanuk, ed. W. B. Saunders, Philadelphia, PA.

McMahon, C. D., T. H. Elsasser, D. R. Gunter, L. G. Sanders, B. P. Steele, and J. L. Sartin. 1998. Estradiol/progesterone implants increase food intake, reduce hyperglycemia and in increase insulin resistance in endotoxic steers. J. Endocrinol. 159:469-478.

McNamara, J. P., and F. Valdez. 2005. Adipose tissue metabolism and production responses to calcium propionate and chromium propionate. J. Dairy Sci. 88:2498-2507.

National Academies. 2001. Dietary Reference Intakes for Vitamin A, Vitamin K, Arsenic, Boron, Chromium, Copper, Iodine, Iron, Manganese, Molybdenum, Nickel, Silicon, Vanadium, and Zinc. National Academy Press, Washington, DC.

NCCLS. 2004. Evaluation of precision performance of quantitative measurement methods: Approved guideline. National Committee for Clinical Laboratory Standards publication EP5-A. Vol. 24, No. 25. 2nd ed. NCLS, Wayne, PA.

NRC. 1996. Nutrient Requirements of Beef Cattle. 7th rev. ed. National Academy Press, Washington, DC.

Sartin, J. L., K. A. Cummins, R. J. Kemppainen, D. N. Marple, C. H. Rahe, and J. C. Williams. 1985. Glucagon, insulin, and growth hormone responses to glucose infusion in lactating dairy cows. Am. J. Physiol. 248:E108-E114.

Sissom, E. K., C. D. Reinhardt, and B. J. Johnson. 2006. Melengestrol acetate alters muscle cell prolification in heifers and steers. J. Anim. Sci. 84:2950-2958.

Smith, K. L., M. R. Waldron, J. K. Drackley, M. T. Socha, and T. R. Overton. 2005. Performance of dairy cows as affected by prepartum dietary carbohydrate source and supplementation with chromium throughout the transition period. J. Dairy Sci. 88:255-263.

Spears, J. W. 2000. Micronutrients and immune function in cattle. Proc. Nutr. Soc. 59:587-594.

Stahlhut, H. S., C. S. Whisnant, K. E. Lloyd, E. J. Baird, L. R. Legleiter, S. L. Hansen, and J. W. Spears. 2006. Effect of chromium supplementation and copper status on glucose and lipid metabolism in Angus and Simmental beef cows. Anim. Feed Sci. Technol. 128:253-265.

Striffler, J. S., J. S. Law, M. M. Polansky, S. J. Bhathena, and R. A. Anderson. 1995. Chromum improves insulin response to glucose in rats. Metabolism 44:1314-1320.

Subiyatno, A., D. N. Mowat, and W. Z. Yang. 1996. Metabolite and hormonal responses to glucose or propionate infusions in periparturient dairy cows supplemented with chromium. J. Dairy Sci. 79:1436-1445.

Sumner, J. M., F. Valdez, and J. P. McNamara. 2007. Effects of chromium propionate on response to an intravenous glucose tolerance test in growing Holstein heifers. J. Dairy Sci. 90:3467-3474.

Vincent, J. B. 2001. The bioinorganic chemistry of chromium (III). Polyhedron 20:1-26.

Weekes, T. E. C. 1991. Hormonal control of glucose metabolism. Pages 183-200 in Physiological Aspects of Digestion and Metabolism in Ruminants. T. Tsuda, Y. Sasaki, and R. Kawashima, ed. Academic Press, San Diego, CA. 